\title{
アジュバント関節炎ラットにおける非ステロイド系抗炎症薬による 胃粘膜傷害性の変化
}

\author{
加藤伸一 \\ 京都薬科大学, $=607-8414$ 京都市山科区御陵中内町 5 番地
}

\section{Changes in Ulcerogenic Response to Non-Steroidal Anti-Inflammatory Drugs (NSAIDs) in Adjuvant Arthritic Rats}

\author{
Shinichi KATO \\ Kyoto Pharmaceutical University, Misasagi, Yamashina, Kyoto 607-8414, Japan
}

(Received July 2, 2001)

\begin{abstract}
Gastroenteropathy is the most common among patients who use non-steroidal anti- inflammatory drugs (NSAIDs) for the treatment of inflammatory disorders. It is known that rheumatoid arthritic (RA) patients are more susceptible to NSAID-induced gastropathy than other NSAID users. This article reviewed our recent studies concerning the influence of arthritis on gastric mucosal integrity in adjuvant-induced arthritic rats. The gastric mucosal lesions induced by indomethacin, one of conventional NSAIDs, were markedly aggravated in arthritic rats. Likewise, the healing of chronic gastric ulcers induced by thermal cauterization was significantly delayed in arthritic rats. The underlying mechanisms of these phenomena observed in arthritic rats may be attributable to the enhancement of iNOS/NO pathway in the former and the less expression of various growth factors in the ulcerated mucosa, such as basic fibroblast growth factors (bFGF) or insulin-like growth factors (IGF-1) in the latter. In addition, we recently found that cyclooxygenase-2 (COX-2) selective inhibitors, such as rofecoxib or celecoxib, induced apparent gastric lesions in arthritic rats, suggesting that a caution should be paid on the use of COX-2 selective inhibitors in RA patients.
\end{abstract}

Key words_ gastric mucosal lesions; adjuvant arthritis; non-steroidal anti-inflammatory drugs (NSAIDs)

\section{はじめに}

非ステロイド性抗炎症薬（NSAID）は臨床にお いて最も繁用される薬剤の 1 つであるが, 消化管障 害をはじめとする副作用を有していることが知られ ており，その使用法が制限されている。特に NSAIDs を長期間使用する慢性リウマチ性関節炎 （RA）患者における消化管障害の発生頻度は, 他の NSAID 使用者と比較しても高く，また重篤である

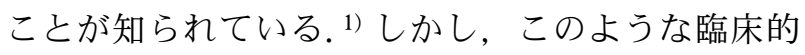
背景があるにもかかわらず，NSAIDsによる消化管 障害と慢性関節炎との関連性に関する基礎研究は少 なく，またその機序も不明なままである.

アジュバント誘発関節炎は RA の動物モデルとし て広く知られており, 抗リウマチ薬あるいは抗炎症 薬の評価に繁用されている。 Schkeyerbach \& Wedde ${ }^{2)}$ はアジュバント誘発関節炎モデルを用い て, 種々の胃粘膜傷害について正常動物と比較検討
し, 代表的な NSAIDs の1つであるアスピリンに より誘起される胃粘膜損傷が関節炎ラットでは有意 に増悪していることを報告した。これに対して Rainsford $^{\text {3) }}$ は, アスピリンの単回あるいは反復投 与により誘起される胃粘膜障害の発生頻度及び程度 は正常ラットとアジュバント関節炎ラットの間には 何ら差は認められないという全く逆の結果を報告し ている。このように, 関節炎発症時における NSAIDs による消化管傷害性の変化に関する研究は 散見されるものの, 必ずしも一致した見解は得られ ていないのが現状である.

NSAIDs は消化管に傷害を発生させるだけでな く, 一旦発生した傷害の治癒に対しても悪影響を及 ぼすことが知られている。実際，ラットにおいて酢 酸により誘起した慢性潰瘍の治癒が, それ単独では 傷害を惹起しない低用量のインドメタシンの連続投 与により有意に遅延することが報告されている. ${ }^{4)}$ 
しかし，このような慢性潰瘍の治癒反応あるいは NSAIDs の連続投与による治癒遅延が関節炎によつ て影響を受けるのかについては不明である。

近年，消化管障害などの副作用の少ない抗炎症薬 としてシクロオキシゲナーゼ (COX) - 2 選択的阻害 薬が開発されている。しかし，COX-2 選択的阻害 薬の消化管障害性を RA 患者とそれ以外の患者で詳 細に比較検討した報告はほとんどなく，また基礎研 究レベルにおいても同様の検討は試されていないの が現状である.

本稿では，関節炎モデルとして最も繁用されてい るアジュバント誘発関節炎ラットを用いた著者の研 究を元に, ${ }^{5-7)}$ 従来の非選択的 NSAID による胃粘 膜傷害性の変化及び慢性潰瘍の治癒に及ぼす関節炎 の影響について概説する。 また，COX-2 選択的阻 害薬の胃粘膜傷害性についても正常及び関節炎ラッ トで比較検討した著者の最近の知見を紹介する。 ${ }^{8)}$

\section{2. インドメタシン誘起胃粘膜損傷に及ぼす影響}

Figure 1A と 1B は，フロイト完全アジュバント （FCA）を雄性 Dark Agouti（DA）ラットの右足踵 に投与し，その後の左右の足容積の変化を示したも のである. 右足，すなわち投与足の足容積は投与後 1 日目から著明に増大し，14-17 日目に最大に達し た. 一方，左非投与足では FCA 投与後最初の 7 日 間は何ら足容積に変化を認めなかったが，10日目 以降から著明な足容積の増大が観察され，その増大 は右投与足と同様に 14-17 日目に最大に達した。

一般的に，アジュバント関節炎モデルは全身性の炎 症モデルであり，非投与足における足浮腫の発現が 全身性炎症の発症を意味するものと考えられてい る。そこでまず，FCA 投与後経日的に代表的な NSAIDs の1つであるインドメタシンの胃粘膜傷害 性について検討した。インドメタシン $(25 \mathrm{mg} / \mathrm{kg})$ の皮下投与は正常ラットにおいても明らかな出血性 の胃粘膜損傷を惹起した (Fig. 1C)。一方関節炎ラ ットにおいては，インドメタシン $(25 \mathrm{mg} / \mathrm{kg})$ は FCA 投与 7 日目では正常ラットとほぼ同程度の損 傷を惹起したが，14 日目ではその損傷は正常ラッ トと比較して著明に増悪していた。関節炎ラットに おけるインドメタシン誘起胃粘膜損傷の増悪は足浮 腫の程度とほぼ相関しており，14 日目を最大とし て以後徐々に低下していた。ゆえに, 関節炎ラット におけるインドメタシン誘起胃粘膜損傷の増悪は
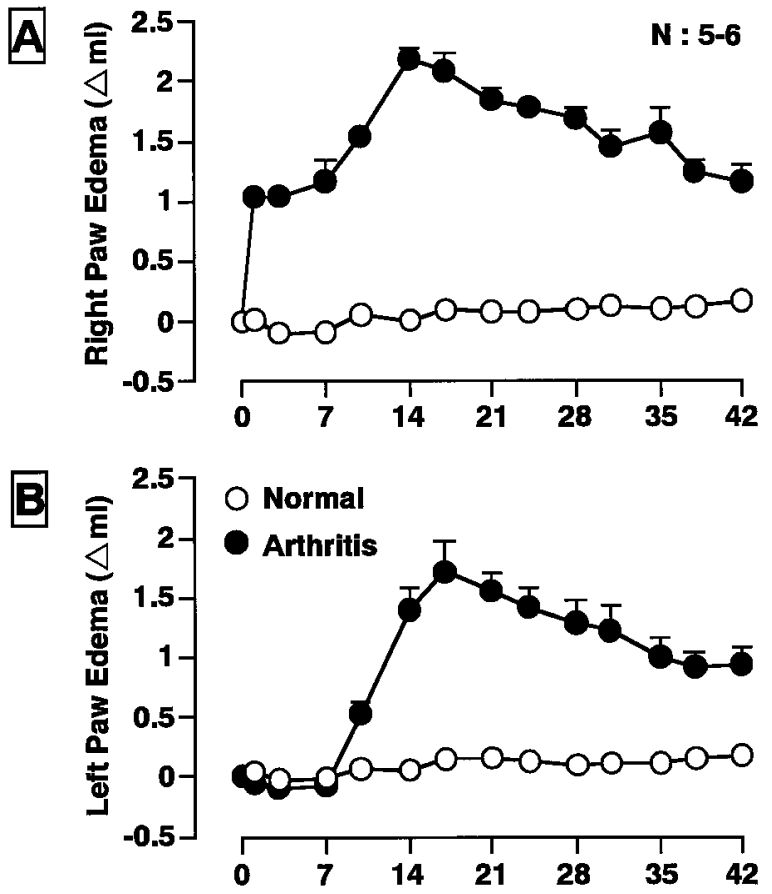

Days After Ad]uvant Injection

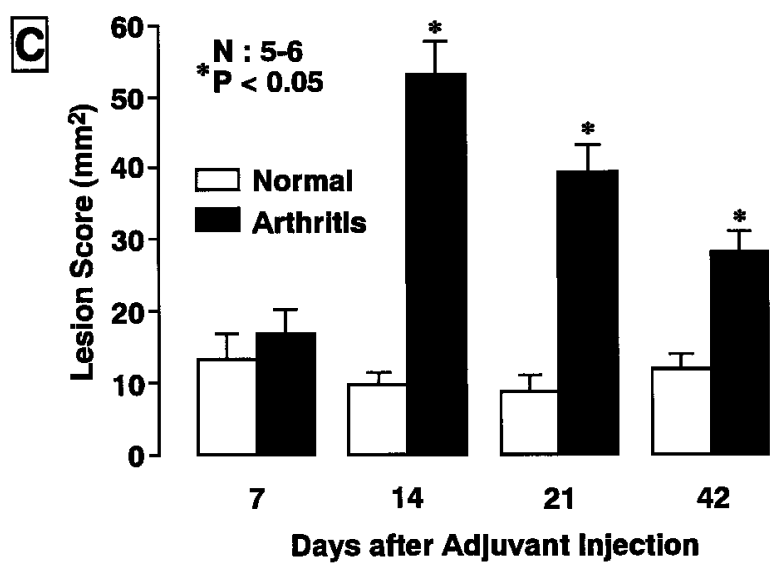

Fig. 1. Changes in Paw Edema and Gastric Ulcerogenic Response to Indomethacin in Normal and Arthritic Rats

Arthritis was induced by injection of Freund's complete adjuvant (FCA) into the planter region of the right hindfoot. The animals were given subcutaneously indomethacin $(25 \mathrm{mg} / \mathrm{kg}) 7,14,21$ and 42 days after FCA injection, and killed $4 \mathrm{hr}$ later. Data are presented as the mean $\pm \mathrm{SE}$ from $5 \sim$ 6 rats per group. *Statistically significant difference from the aged and batchmatched normal rats at $p<0.05$. A \& B: the right and left paw edema, C: the gastric mucosal lesions induced by indomethacin.

FCA 投与後の全身性炎症反応の結果生じるもので あると推察される。またインドメタシンのみなら ず，アスピリンの経口投与により誘起される胃粘膜 損傷も同様に関節炎ラットでは有意に増悪すること も観察されており, ${ }^{9)}$ NSAIDs による胃粘膜傷害性 の増悪はアジュバント関節炎ラットにおいて普遍的 に認められる現象であると考えられる。

インドメタシンをはじめとする種々の胃粘膜損傷 
において，胃酸が損傷発生あるいは増悪因子として 重要な役割を果たしていることはよく知られてい る.アジュバント関節炎においては血清ガストリン 量の上昇により胃酸分泌が著明に増大していること が報告されており, 10,11) この酸分泌の増大がアスピ リン誘起胃粘膜損傷の増悪に関与している可能性が 指摘されている. ${ }^{2)}$ 実際, 我々もアジュバント関節 炎ラットの基礎胃酸分泌を幽門結紮法により検討し たところ，関節炎ラットの基礎胃酸分泌量は正常ラ ットと比較して約 2 倍に増大していることを確認し ている. しかし, 外因性に $150 \mathrm{mM}$ 塩酸を経口投与 することにより内因性の酸分泌変化をマスクした条 件下においても，関節炎ラットにおいてはインドメ タシン誘起胃粘膜損傷の増悪が同様に観察された.

したがって, インドメタシン誘起胃粘膜損傷の増悪 現象は内因性の酸分泌の増大に起因したものではな いと考えられる。

近年, 胃粘膜防御機構の調節因子として以前から 知られているプロスタグランジンに加えて，一酸化 窒素（NO）が注目されている. 12）実際，外因性に 投与された NOが胃粘膜保護作用を示すことなど が数多く報告されている. ${ }^{13)}$ 一方，NO はこのよう な防御的な役割だけでなく, 大量に産生された場合
には逆に傷害性に作用することも知られている。特 に誘導型 NO 合成酵素（iNOS）から産生される大 量の NO は消化管においても傷害を惹起すること が報告されており, 14-18) 種々の消化管病変との関 連性が指摘されている。そこで，関節炎ラットにお けるインドメタシン誘起胃粘膜損傷の増悪における NOの関与を検討する目的で, 非選択的 NOS 阻害 薬である NG-nitro-L-arginine methyl ester (L-NAME) 及びiNOS を比較的選択的に阻害するアミノグアニ ジンを用いて検討した（Fig. 2)。正常ラットにお けるインドメタシン誘起胃損傷はこれら両阻害薬に よっては何ら影響を受けなかったが，関節炎ラット における胃粘膜損傷の増悪は L-NAME 及びアミノ グアニジンのいずれによっても有意に抑制された. また，胃粘膜 iNOS 酵素活性及び iNOS mRNA 発 現をそれぞれ L- アルギニンから L- シトルリンへの 変換及び RT-PCR 法を用いて検討したところ, 正 常ラット胃粘膜では iNOS 活性並びに iNOS mRNA 発現はほとんど認められなかったのに対し，関節炎 ラットでは著明な iNOS 活性の増大並びに iNOS mRNA 発現が観察された。これらの結果から, 関 節炎ラットにおけるインドメタシン誘起胃粘膜損傷 の増悪には，おそらくiNOS 由来の NO が関与して
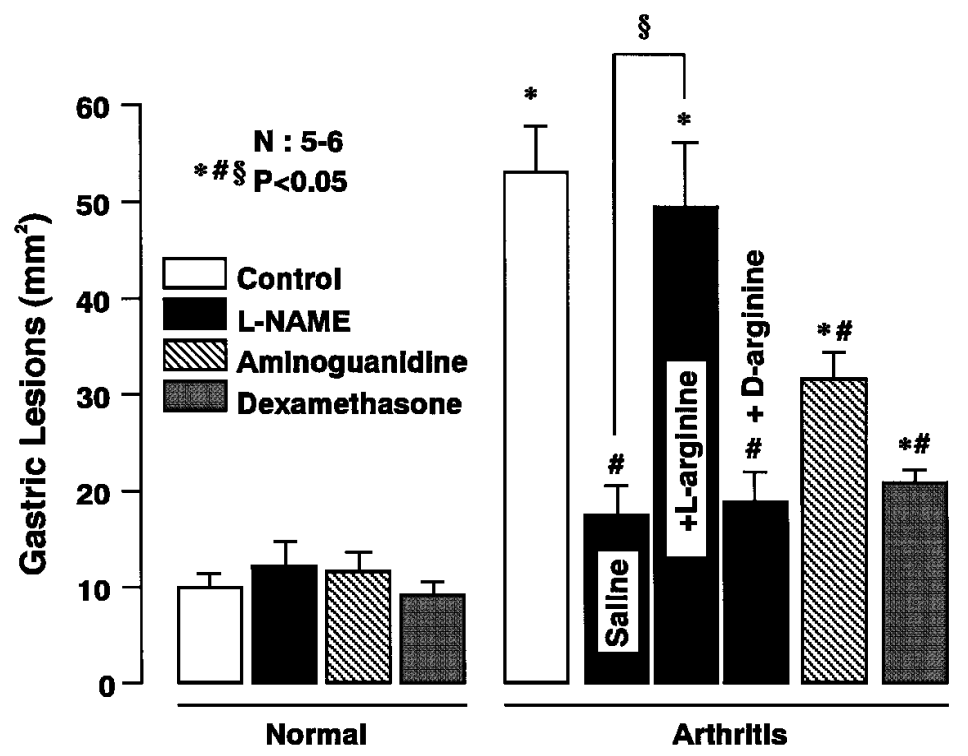

Fig. 2. Effects of NG-Nitro-L-Arginine Methyl Ester (L-NAME), Aminoguanidine and Dexamethasone on Indomethacin-Induced Gastric Lesions in Normal and Arthritic Rats

The animals were given subcutaneously indomethacin $(25 \mathrm{mg} / \mathrm{kg}) 14$ days after FCA injection, and killed $4 \mathrm{hr}$ later. L-NAME $(20 \mathrm{mg} / \mathrm{kg})$ and aminoguanidine $(20 \mathrm{mg} / \mathrm{kg})$ were given subcutaneously twice daily, $18 \mathrm{hr}$ and $0.5 \mathrm{hr}$ before indomethacin, while dexamethasone $(3 \mathrm{mg} / \mathrm{kg})$ was given subcutaneously twice daily, 18 $\mathrm{hr}$ and $2 \mathrm{hr}$ before indomethacin. L- or D-arginine $(500 \mathrm{mg} / \mathrm{kg})$ was administered intraperitoneally every $0.5 \mathrm{hr}$ before L-NAME treatments. Data are presented as the mean $\pm \mathrm{SE}$ from $5 \sim 6$ rats per group. Statistically significant difference at $p<0.05$; ${ }^{*}$ from control (vehicle alone), \#from the corresponding group in normal rats, §from saline (L-NAME alone) in arthritic rats. 
いるものと推察される.

\section{3. 慢性胃潰瘍の治癒に及ぼす影響}

臨床において, NSAIDs を慢性的に使用する患者 は高頻度に胃潰瘍を発症することが知られている。 特に RA 患者では NSAIDs を使用する期間が長い ばかりでなく，それ以上に胃潰瘍などの消化管障害 の発生頻度が高い傾向があることが知られてい る. ${ }^{1)}$ 実験動物レベルにおいては, 実験的に作成し た慢性潰瘍の治癒がインドメタシンの連続投与によ り有意に遅延することが報告されている.4)しか し, 慢性潰瘍の治癒反応が関節炎によって影響を受 けるのか，またインドメタシンなどの NSAIDs 連 続投与による治癒遅延が関節炎によってさらに修飾 されるのかについては不明である。そこで著者は, 慢性潰瘍モデルとして知られている焼灼潰瘍モデル を用いて, 関節炎ラットにおける慢性潰瘍の治癒反 応を正常ラットと比較検討した. 左非投与足がまだ 浮腫を発症していない FCA 投与 7 日目に 70 度に 熱した金属製のコテ（直径 $9 \mathrm{~mm} ）$ を 20 秒間ラッ 卜の胃漿膜に接触させることにより慢性潰瘍を惹起 した。潰瘍面積は作製 3 日後に最大に達し, その際 の正常及び関節炎ラットの潰瘍面積はほぼ同程度あ つた（Fig. 3)。正常ラットの潰瘍は経日的に治癒 縮小したが, 関節炎ラットにおける治癒反応は正常 ラットと比較して有意に遅延していた。すなわち,
関節炎ラットではインドメタシンなどによる胃粘膜 傷害性が増大していると同時に，一旦発生した潰瘍 の治癒反応も遅延していることが明らかとなつた. また，インドメタシンの連続投与は慢性潰瘍の治癒 を遅延させることが知られているが, 関節炎ラット における慢性潰瘍の治癒遅延をインドメタシンの連 続投与はさらに助長することが判明した.

関節炎ラットにおける慢性潰瘍の治癒遅延の機序 を検討するため, まずインドメタシン誘起胃粘膜損 傷の増悪に関連していることが判明している iNOS /NO の関与について検討した（Fig. 4)。 L-NAME 及びアミノグアニジンの連続投与は正常ラットにお ける慢性潰瘍の治癒反応をやや遅延させる傾向が認 められたものの, 統計学的に有意なものではなかっ た。一方, 関節炎ラットにおける慢性潰瘍の治癒遅 延に対してこれらの両薬物は何ら影響を及ぼさなか つたことから, 関節炎ラットにおける治癒遅延現象 には iNOS/NO は関与しないものと考えられる.

先述のごとく，著者はアジュバント関節炎ラット では基礎胃酸分泌が正常ラットに比較して有意に増 大していることを観察している。一般に, 胃酸分泌 は慢性潰瘍の治癒に対する遅延因子の 1 つとして知 られており, ${ }^{19,20)}$ 酸分泌抑制薬の連続投与が酢酸誘 起の慢性潰瘍の治癒を有意に促進することが報告さ

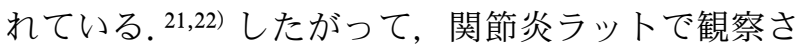

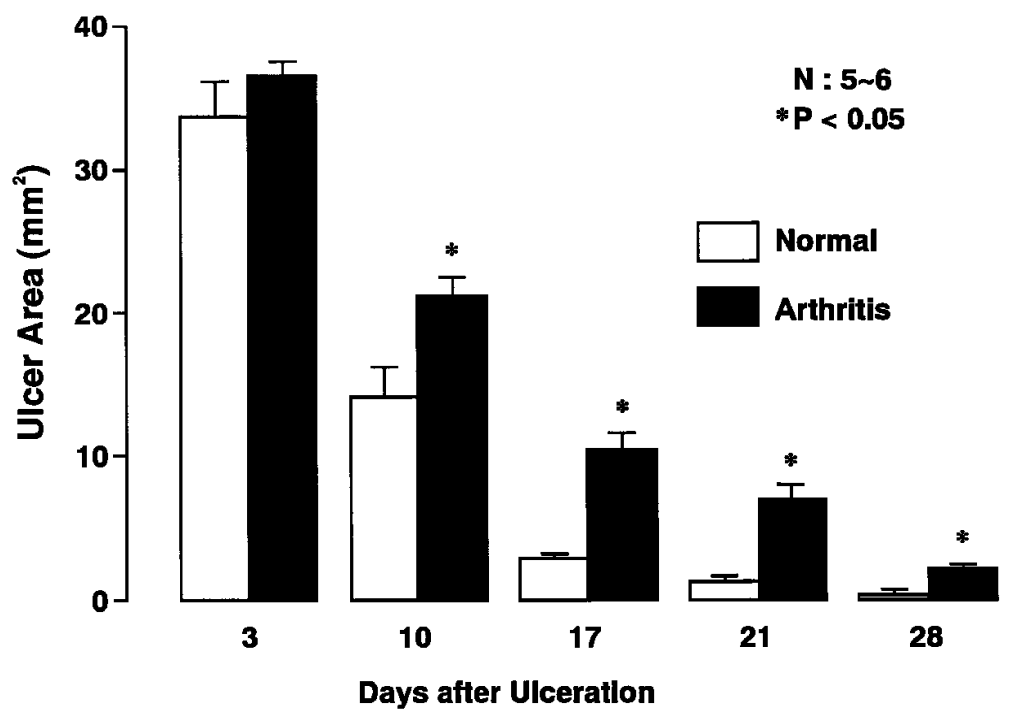

Fig. 3. Changes in Ulcer Area in Normal and Arthritic Rats after Ulceration

The chronic gastric ulcer was induced by thermal cauterization $\left(70^{\circ} \mathrm{C}, 30 \mathrm{sec}\right.$.) on day 7 after the FCA injection. The animals were killed $3,10,17,21$ and 24 days after ulceration. Data are presented as the mean \pm SE from $5 \sim 6$ rats per group. *Statistically significant difference from the aged and batch-matched normal rats at $p<0.05$. 


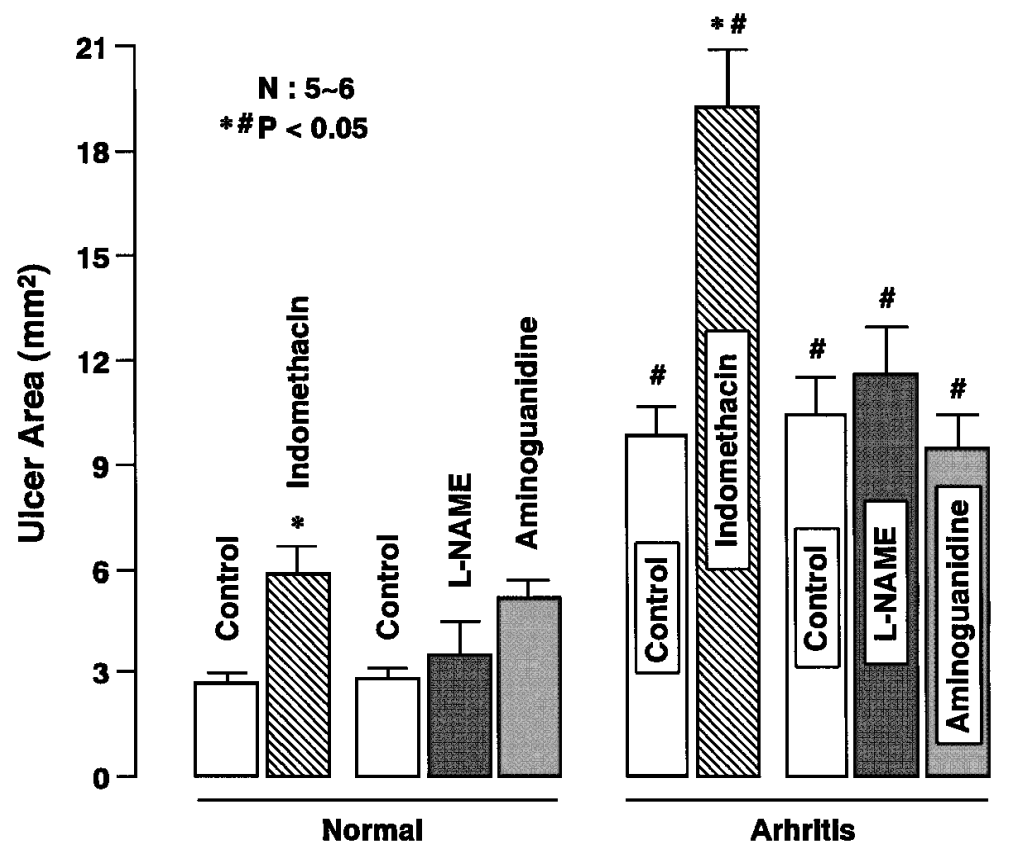

Fig. 4. Effects of Indomethacin, L-NAME and Aminoguanidine on the Healing of Chronic Gastric Ulcers in Normal and Arthritic Rats.

The animals were administered subcutaneously indomethacin $(1 \mathrm{mg} / \mathrm{kg})$ once daily, and L-NAME $(20 \mathrm{mg} / \mathrm{kg})$ or aminoguanidine $(20 \mathrm{mg} / \mathrm{kg})$ twice daily for 14 days, starting from days after ulceration, and they were killed 17 days later. Data are presented as the mean \pm SE from $5 \sim 6$ rats. Statistically significant difference at $p<0.05$, *from the respective control (vehicle alone), \#from the corresponding group in normal rats.

れた慢性潰瘍の治癒遅延が酸分泌の増大に関連して いる可能性が十分に考えられる。実際著者は，プロ トンポンプ阻害薬であるオメプラゾールの連続投与 が正常及び関節炎ラットにおける慢性潰瘍の治癒を 有意に促進することを認めた．当然のことながら， オメプラゾールは正常ラットにおける治癒も有意に 促進し，またオメプラゾール処置下においても関節 炎ラットにおける慢性潰瘍の治癒反応は正常ラット に比較して有意に遅延しており, 胃酸分泌以外の機 序が推察される。

以前より慢性潰瘍の治癒において, 種々の増殖因 子の関与が想定されている. ${ }^{23)}$ 実際, 慢性潰瘍の治 癒反応は塩基性線維芽細胞増殖因子（bFGF）など の連続投与により有意に促進することが報告されて いる. ${ }^{24-26)}$ 著者も bFGF の酸安定型誘導体である CS-23 を連続投与したところ, 正常ラットにおける 慢性潰瘍の治癒反応を有意に促進した（Fig. 5A）。 さらに興味深いことに, 関節炎ラットにおいて観察 された慢性潰瘍の治癒遅延に対しても有意な促進作 用が観察され, その作用はオメプラゾールと比較し てもより強力であった。 そこで，正常及び関節炎ラ ットにおける胃粘膜 bFGF 発現量を Western blot
法により検討した（Fig. 5B）。正常ラットでは潰瘍 作製直後から著明な bFGF 発現の増大が観察され たが，関節炎ラットでそのような増大反応は著明に 減弱していることが判明した。 さらに, 他の増殖因 子についても検討してみたところ, 同様の発現低下 はインスリン様增殖因子（IGF）-1 においても認め

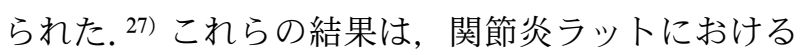
慢性潰瘍の治癒遅延の機序として, bFGF や IGF-1 をはじめとする種々の細胞増殖因子の発現低下が関 与している可能性を示唆するものである.

\section{COX-2 選択的阻害薬の胃粘膜傷害性}

近年, 消化障害などの副作用の少ない抗炎症薬と していくつかの COX-2 選択的阻害薬が開発されて おり, 臨床においても注目されている. しかし, 消 化管粘膜の統合性維持における COX アイソザイム の役割については様々な報告が試されており，ある 状況下における胃粘膜防御においては COX-1 のみ ならず COX-2 由来の PGs も重要な役割を果たして いることが示されている. ${ }^{28)}$ また, 一旦発生した潰 瘍の治癒過程においてもCOX-2 が重要な役割を果 たしており, 従来の非選択的 NSAIDs と同様に COX-2 選択的阻害薬が潰瘍治癒を有意に遅延させ 

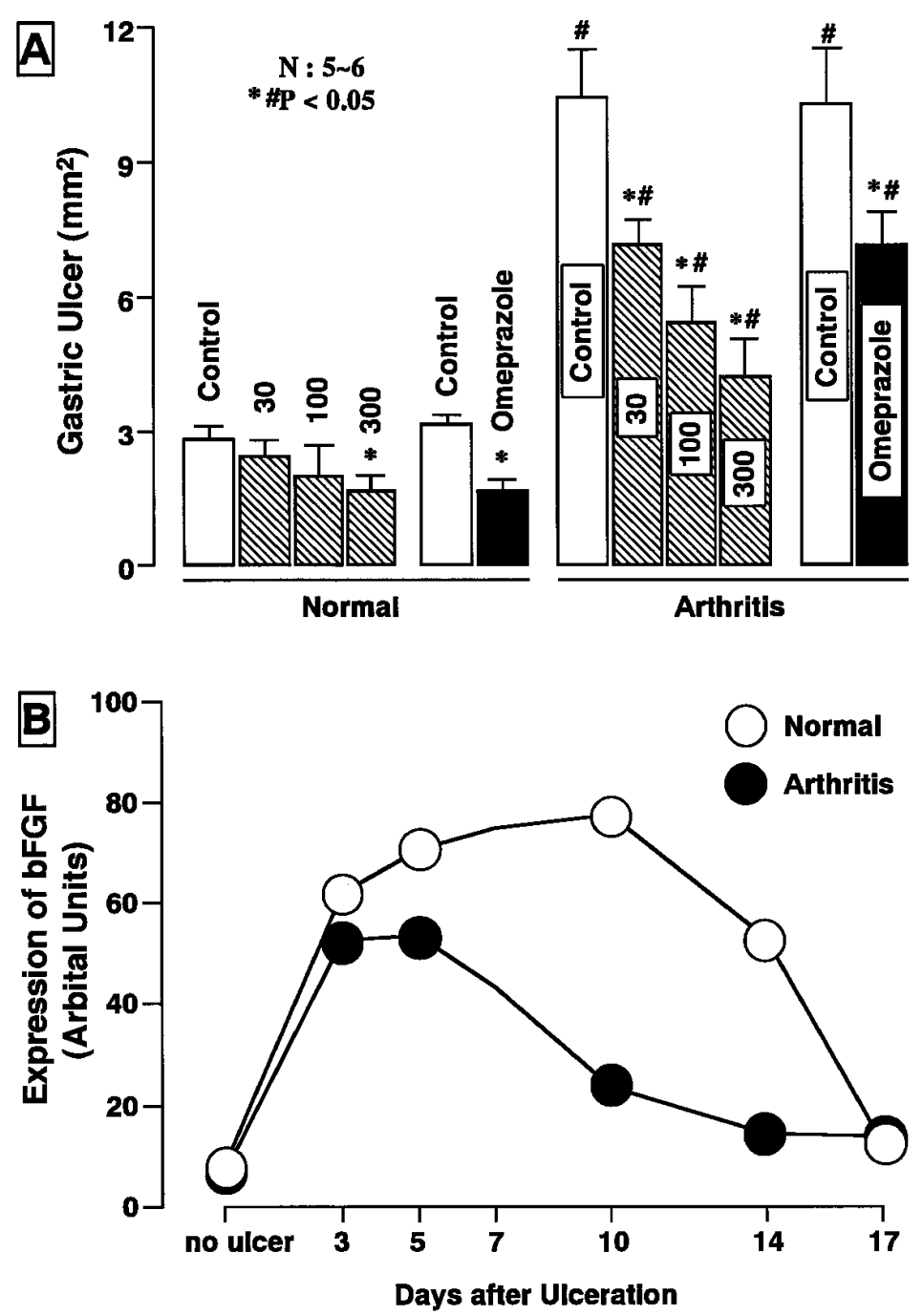

Fig. 5. Effects of CS-23 or Omeprazole on the Healing of Chronic Gastric Ulcers (A) and Expression of Basic Fibroblast Growth Factor (bFGF) after Ulceration in Normal and Arthritic Rats (B)

The animals were administered subcutaneously CS-23 $(30 \sim 300 \mathrm{ng} / \mathrm{kg})$ twice daily or omeprazole $(30 \mathrm{mg} / \mathrm{kg})$ once daily for 14 days, starting from 3 days after ulceration, and they were killed 17 days later. Data are presented as the mean \pm SE from $5 \sim 6$ rats per group. Statistically significant difference at $p<0.05$, ${ }^{*}$ from control (vehicle alone), \# from the corresponding group in normal rats. On the other hand, the expression of bFGF was determined using Western blot analyses 3 , $5,7,10,14$ and 17 days after ulceration.

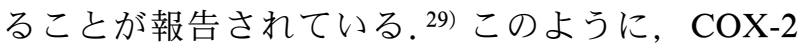
選択的阻害薬の安全性については疑問な点も多く, より詳細な検討が必要であると思われる。それゆ え，胃粘膜傷害性が増大していることが証明されて いる関節炎ラットにおける COX-2 選択的阻害薬の 傷害性を検討することは, 臨床的観点からも非常に 興味深い.

そこで著者は，この点についてアジュバント関節 炎ラットを用いて COX-2 選択的阻害薬の胃粘膜傷 害性について正常ラットと比較検討した。正常ラッ トにおいては，これまでの多くの報告と同様に COX-2 選択的阻害薬であるロフェコキシブ並びに
セレコキシブは, $100 \mathrm{mg} / \mathrm{kg}$ の高用量でも胃粘膜に 対しては全く傷害性を示さなかった（Fig. 6)。こ れに対して，FCA 投与 14 日目の関節炎ラットでは インドメタシンと同様に両 COX-2 選択的阻害薬は 用量依存的な胃粘膜損傷を惹起した。元来, COX-1 は胃粘膜に恒常的に発現しており, 正常胃 粘膜における恒常性維持に重要な役割を果たしてい るものと考えられてきた。，一方，COX-2 は平常時 にはほとんど発現しておらず，炎症などの病態部位 で発現する誘導型の酵素であり, 炎症反応と密接に 関連していることが知られている. ${ }^{30-32)}$ すなわち, COX-2 選択的阻害薬は胃粘膜などの恒常性維持に 


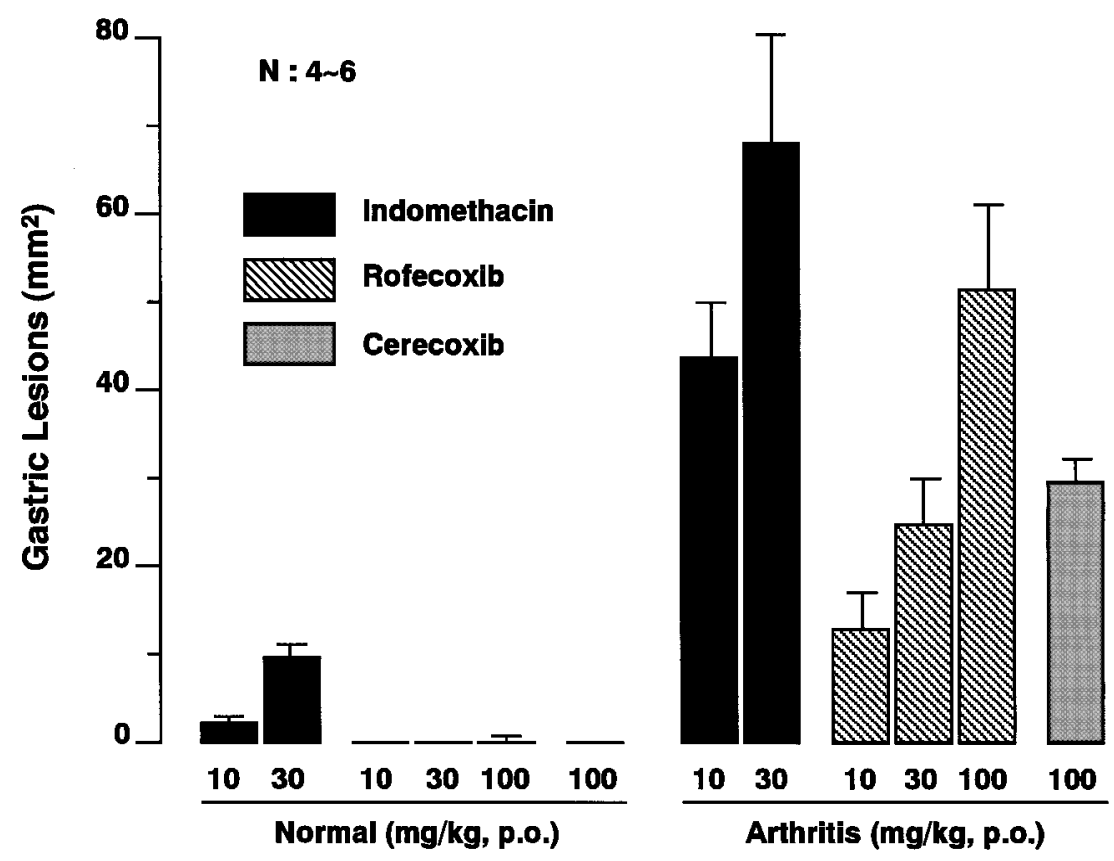

Fig. 6. Changes in Ulcerogenic Response to Indomethacin, Rofecoxib and Celecoxib on in Normal and Arthritic Rats

The animals were given orally indomethacin $(10$ and $30 \mathrm{mg} / \mathrm{kg})$, rofecoxib $(10 \sim 100 \mathrm{mg} / \mathrm{kg})$ and celecoxib $(100 \mathrm{mg} / \mathrm{kg}) 14$ days after FCA injection, and killed $4 \mathrm{hr}$ later. Data are presented as the mean $\pm \mathrm{SE}$ from $4 \sim 6$ rats per group.

重要である COX-1 由来の PG 産生には影響を与え ることなく, 炎症部位における $\mathrm{COX}-2$ 由来の $\mathrm{PG}$ 産生のみを阻害する結果, 消化管障害などの副作用

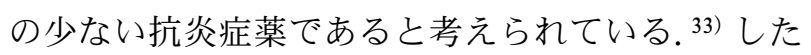
がって，COX-2 選択的阻害薬が関節炎ラットにお いて胃粘膜障害を惹起したことは，これらの薬剤の 臨床使用において極めて重要な意義を持つものと思 われる。また，著者は正常ラットの胃粘膜では COX-2 はほとんど発現していなかったのに対し て，関節炎ラットでは著明な COX-2 発現が観察さ れ，また胃粘膜 $\mathrm{PGE}_{2}$ 含量も有意に増大しているこ とを認めている. さらに, 関節炎ラットの胃粘膜で は血管透過性が正常ラットと比較して有意に立進し ていることも観察された。血管透過性の亢進は胃粘 膜の微小循環系などに何らかの傷害が存在している ことを示唆するものであり, そのような傷害の結果 COX-2 などの炎症に関連する誘導型酵素が発現し た可能性が推察される. 実際, 著者は胃粘膜に軽微 な傷害を与えた場合にも COX-2 発現が増大するこ とを報告している. ${ }^{34)}$ すなわち, 関節炎ラットでは 胃粘膜に血管透過性の充進を伴った傷害が存在して いるが，COX-2 由来の PG 産生により傷害の更な る進展が防御されていた可能性が考えられる。関節
炎ラットで認められた胃粘膜血管透過性の亢進の機 序については不明であるが，おそらく関節炎に付随 した痛みなどによる慢性的なストレスによる可能性 も考えられる. 今後, この点に関する更なる検討が 必要であると思われる。

\section{5. 結語}

本研究において, アジュバント関節炎ラットでは インドメタシンなどの NSAIDs による胃粘膜傷害 性が正常ラットと比較して著明に増悪していること が明らかとなった。 その増悪機序としては, 関節炎 ラットの胃粘膜における iNOS 由来の NOが関与し ているものと推察される。 また, 関節炎ラットでは 慢性胃潰瘍の治癒も正常ラットと比較して有意に遅 延していることが判明した. 関節炎ラットの胃粘膜 では潰瘍発生後に認められる bFGF や IGF-1 など の種々の増殖因子の発現増加が著明に低下してお り, そのことが治癒遅延の原因であると考えられ る. さらに, 近年消化管障害性の少ない抗炎症薬と して注目されている COX-2 選択的阻害薬が関節炎 ラットでは明らかな胃粘膜損傷を惹起することを見 出した。 したがって, 関節炎ラットにおいては, COX-1 のみならず, COX-2 もまた胃粘膜防御にお いて重要な役割を果たしている可能性が推察される. 
本研究は，実際の RA などの慢性的な全身性炎症 状態における NSAIDs の消化管に対する影響を検 討したものであり, 臨床的観点から極めて重要であ ると思われる。実際，関節炎ラットにおける NSAIDs 誘起胃粘膜損傷の増悪や慢性潰瘍の治癒遅 延の機序に関して新たな概念を提唱することができ たことは極めて意義深いものである。また， COX-2 選択的阻害薬は元来胃粘膜傷害性が少ない と考えられていたが, 関節炎ラットにおいては従来 の NSAIDs に比べれば弱いものの，明らかな胃粘 膜傷害性を示したことから, 臨床, 特に RA 患者に 対する使用においては慎重になる必要性があると思 われる. 今後, RAなどの病態をターゲットとした 抗炎症薬などの開発においては, 実際の臨床を踏ま えて, 関節炎を発症させた動物を用いて基礎研究を 行っていくことが重要であると考えられる.

\section{謝辞 本総説で紹介させていただいた研究成果} は，京都薬科大学薬物治療学教室において行われた ものであり，ご指導ご助言を賜りました竹内孝治教 授並びにご協力を頂きました同教室の皆様に厚く御 礼申し上げます。なお, 本研究の一部は文部省科学 研究費補助金によって行われたものであり，併せて 感謝の意を表します。

\section{REFERENCES}

1) Fries J. F., Miller S. R., Spitz P. W., Williams C. A., Hubert H. B., Bloch D. A., Gastroenterology, 96, 647-655 (1989).

2) Schleyerbach R., Wedde H., Agents \& Actions, 15, 392-397 (1984).

3) Rainsford K. D., Dig. Dis., 23, 521-530 (1978).

4) Wang J. Y., Yamasaki S., Takeuchi K., Okabe S., Gastroenterology, 96, 393-402 (1989).

5) Kato S., Tanaka A., Kunikata T., Nishijima M., Takeuchi K., Aliment. Pharmacol. Ther., 13, 833-840 (1999).

6) Kato S., Tanaka A., Kunikata T., Mizoguchi H., Takeuchi K., Aliment. Pharmacol. Ther., 14, 18-25 (2000).

7) Kato S., Ogawa Y., Tanaka A., Kunikata T., Takeuchi K., Digestion, 63, 171-179 (2001).

8) Kato S., Ogawa Y., Kunikata T., Watanabe
T., Arakawa T., Takeuchi K., Gastroenterology, 120, A-143 (2001).

9) Kato S., Suzuki K., Ukawa H., Komoike Y., Takeuchi K., Dig. Dis. Sci., (2001) in press.

10) Rooney P. J., Dick W. C., Nature, 246, 497498 (1973).

11) Mathur P. P., Smith R. D., J. Pharmacol. Exp. Ther., 212, 333-336 (1979).

12) Moncada S., Palmer R. M. J., Higgs R. A., Pharmacol. Rev., 109-142 (1991).

13) Lopez-Belmonte J., Whittle B. J. R., Moncada S., Br. J. Pharmacol., 108, 73-78 (1993).

14) Ribbons R. A., Zhang X. J., Thompson J. H., Greenberg S. S., Moore W. M., Kornmeier C. M., Currie M. G., Lerche N., Blanchard J., Clark D. A., Gastroenterology, 108, 705-711 (1995).

15) Mourelle M., Vllaseca J., Guarner P., Salas A., Malagelada J. R., Am. J. Physiol., 270, G425-G430 (1996)

16) Yasuhiro T., Ukawa H., Kato S., Takeuchi K., J. Physiol. (Paris), 91, 131-138 (1997).

17) Yasuhiro T., Korolkiewicz R. P., Kato S., Takeuchi K., Pharmacol. Res., 36, 333-338 (1997)

18) Whittle B. J. R., Laszlo F., Evans S. M., Moncada S., Br. J. Pharmacol., 116, 22862290 (1995).

19) Halter F., Barbezat G. O., Van Hoorn-Hickman R., Van Hoorn W. A., Dig. Dis. Sci., 25, 916-920 (1980).

20) Okabe S., Pfeiffer C. J., Am. J. Dig. Dis., 17, 619-629 (1972).

21) Yamamoto O., Okada M., Okabe S., Dig. Dis. Sci., 29, 394-401 (1984).

22) Inauen W., Wyss P. A., Kayser S., Baumgartner A., Schurer-Maly C. C., Koelz H. R., Halter F., Gastroenterology, 95, 636-641 (1988).

23) Folkman J., Klagsbrun M., Sciences, 235, 442 -447 (1987).

24) Folkman J., Szabo S., Strovroff M., McNeil P., Li W., Shing Y., Ann. Surg., 214, 414-427 (1991).

25) Satoh H., Shino A., Sato F., Asano S., Murakami I., Inatomi N., Nagaya H., Katoh K., Szabo S., Folkman J., Jpn. J. Pharmacol., 73, 59-71 (1997).

26) Szabo S., Folkman J., Vattay P., Morales R. 
E., Pinkus G. S., Kato K., Gastroenterology, 106, 1106-1111 (1994).

27) Kato S., Tanaka A., Ogawa Y., Kanatsu K., Seto K., Yoneda T., Takeuchi K., Med. Sci. Monit., 7, 20-25 (2001).

28) Yamamoto H., Tanaka A., Kunikata T., Hirata T., Kato S., Takeuchi K., J. Physiol. Paris, 93, 405-412 (1999).

29) Mizuno H., Sakamoto C., Matsuda K., Wada K., Uchida T., Noguchi H., Akamatsu T., Kasuga M., Gastroenterology, 112, 387-397 (1997).

30) Xie W., Chipman J. G., Robertson D. L., Erikson R. L., Simmons D. L., Proc. Natl. Acad. Sci. U.S.A., 96, 7563-7568 (1999) .

31) Vane J. R., Mitchell J. A., Appleton I., Tom- linson A., Bishop-Bailey D., Croxtall J., Willoughby D. A., Proc. Natl. Acad. Sci. U.S.A., 91, 2046-2050 (1994).

32) Dubois R. N., Abramson S. M., Crofford L., Gupta R. A., Simon L. S., Van De Putte L. B., Lipsky P. E., FASEB J., 12, 1063-1073 (1998).

33) Brooks P., Emery P., Evans J. F., Fenner H., Hawkey C. J., Patrono C., Smolen J., Breedveld F., Day R., Dougados M., Ehrich E. W., Gijon-Banos J., Kvien T. K., Van Rijswijk M. H., Warner T., Zeidler H., Rheumatology (Oxford), 38, 779-88 (1999).

34) Hirata T., Ukawa H., Yamakuni H., Kato S., Takeuchi K., Br. J. Pharmacol., 122, 447-454 (1997). 